Japan. J. Med. Sci. Biol., 29, 151-163, 1976

\title{
STUDIES ON DELAYED-TYPE HYPERSENSITIVITY TO HEN EGG-WHITE LYSOZYME
}

\section{PEPTIDE FRAGMENTS OF LYSOZYME INDUCING DELAYED-TYPE HYPERSENSITIVITY*}

\author{
Kozo YOKOMURO and ReIKo HOMMA \\ Department of Microbiology and Immunology, Nippon Medical School, Sendagi, Bunkyo-ku, \\ Tokyo, and Department of General Biologics Control, National Institute of Health, \\ Kamiosaki, Shinagawa-ku, Tokyo 141, Japan
}

(Received: January 28, 1976)

\begin{abstract}
SUMMARY : Eleven peaks were separated by Carboxymethyl-cellulose column chromatography of peptic digest of lysozyme. Being stronger in antigenic activity, two peaks of them, P-3 and P-9, were selected and purified further respectively by Amberlite IRC-50 and Sephadex G-50 column chromatography. As the results, PP-3 and PP-9 were obtained each as a single peak.

For estimation of their capacities to induce delayed-type hypersensitivity, the antigen-induced ${ }^{3} \mathrm{H}$-thymidine incorporation, the migration inhibition of peritoneal cells and the delayed-type skin reaction were tested in guinea pigs immunized with native lysozyme or any of its fractions. PP-9 was almost as active as intact lysozyme in these capacities. On the other hand, PP-3 showed a slight inhibition of migration of peritoneal cells and no stimulation of ${ }^{3} \mathrm{H}$-thymidine incorporation into the lymph node cells. Moreover, the delayed-type skin reaction elicited by PP-3 was always weaker than that elicited by PP-9.

Guinea pigs immunized with either PP-3 or PP-9 were also tested for these reactions. PP-9 and native lysozyme elicited these reactions in guinea pigs immunized with PP-9, but PP-3 did not. On the other hand, PP-3 and lysozyme elicited these reactions in those immunized with PP-3, but PP-9 did not.

The possibility of recognition of two functionally different areas, one for production of the circulating antibody and the other for induction of delayed-type hypersensitivity, on the lysozyme molecule was discussed.
\end{abstract}

\section{INTRODUCTION}

It has been reported that the antigenic site on a molecule recognized by immunocytes for production of humoral antibody is distinct from that for induction of delayed-type hypersensitivity with synthetic polypeptides (Schlossman, Herman and Yaron, 1969), flagellin (Ichiki and Parish, 1972) and glucagon (Senyk et al., 1971) as immunogens. The results with flagellin and its acetoacetylated derivatives as immunogens showed no serological cross reactivity

\footnotetext{
* A part of this study was reported at the IInd and the IIIrd Annual Meetings of Japanese Society of Immunology (1972 and 1973).

横室公三（日本医科大学 微生物学免疫学教室 文京区千駄木 1-1-5)

本間玲子（国立予防衛生研究所一般検定部）
} 
between these antigens but a significant degree of cross reactivity was observed with respect to delayed-type hypersensitivity measured by the footpad swelling technique (Ichiki and Parish, 1972). It was demonstrated with the enzymatically digested products of glucagon that the $\mathrm{N}$-terminal area of the molecule was found to be the antigenic determinant for circulating antibody, while the C-terminal part was recognized by antigen-reactive cells (Senyk et al., 1971). It was recently reported that there was cross reactivity between lysozyme and its reduced, Scarboxymethylated derivative (GM-lysozyme) in delayed-type skin reaction, but not with respect to humoral antibodies (Thompson, Harris and Benjamini, 1972). A similar observation was presented by the footpad swelling test in mice immunized with lysozyme or CM-lysozyme (Sugimoto et al., 1975). The results observed between hen egg-white lysozyme and bovine $\alpha$-lactoalbumine indicated a cross reaction with regard to the delayed-type hypersensitivity level but no cross reaction with each other on the circulating antibody level (Maron et al., 1972).

It was already shown by Shinka et al. (1967) and Fujio et al. (1968) that their fractions 7 and 17 isolated from the pepsin digest of hen egg-white lysozyme had an antigenic activity against rabbit antilysozyme serum. We also separated 11 fractions from pepsin-digested lysozyme by the same method as Shinka et al. (1967). Our fractions PP-3 and PP-9 were correspond to their Fr. 7 and Fr. 17, respectively.

In this report, we will present the data demonstrating that PP-9 elicits strong delayed-type hypersensitivity, while PP-3 slight reaction in guinea pigs immunized with lysozyme. Based on the data, we will discuss the possibility that different sites on the lysozyme molecule are recognized by immunocytes for production of antibody and for elicitation of delayed-type hypersensitivity.

\section{MATERIALS AND Methods}

Lysozyme: Hen egg-white lysozyme $(6 \times$ crystalized) was purchased from Seikagaku Kogyo Co., Tokyo. Lysozyme used for immunization of guinea pigs was purified further on an IRC-50 (XE-64) column by the method of Hirs, Moore and Stein (1953).

Animals: Guinea pigs (300-400 g, strain Hartley, purchased from Shizuoka Jikken-Dobutsu Co., Shizuoka) were used throughout the experiments.

Digestion of lysozyme and fractionation of the digest: Digestion of lysozyme with pepsin was performed by the procedures of Shinka et al. (1967) with slight modifications. One and half grams of lysozyme dissolved in $150 \mathrm{ml}$ of $0.1 \mathrm{~N} \mathrm{HCl}$ (adjusted to $\mathrm{pH} 1.62$ with $10 \mathrm{~N} \mathrm{NaOH}$ ) was added with $0.75 \mathrm{ml}$ of a pepsin (twice crystallized and lyophilized; Shigma Chemical Co., St. Louis, Mo.) solution in saline at a concentration of $1.0 \mathrm{mg} / \mathrm{ml}$. The mixture was incubated at $40 \mathrm{C}$ for $80 \mathrm{~min}$ and then lyophilized.

Three hundred milligrams of the lyophilized material was dissolved in $10 \mathrm{ml}$ of $0.05 \mathrm{M}$ acetate buffer, $\mathrm{pH} 3.85$, and applied to a CM-cellulose (0.5 meq/g 200-400 mesh) (Seikagaku-Kogyo Co.) column $(3 \times 40 \mathrm{~cm})$ equilibrated with the 
same buffer. Elution was made at $25 \mathrm{C}$ at a flow rate of $170-180 \mathrm{ml} / \mathrm{hr}$ with

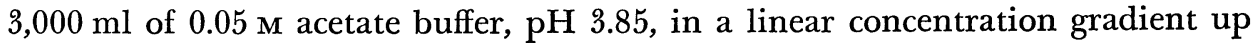
to $0.15 \mathrm{M} \mathrm{NaCl}$, followed by a linear gradient mixture of $1,000 \mathrm{ml}$ each of $0.05 \mathrm{M}$ acetate buffer, $\mathrm{pH} 3.85$, containing $0.15 \mathrm{M} \mathrm{NaCl}$ and $0.2 \mathrm{M}$ phosphate buffer, $\mathrm{pH}$ 8.0. The main peaks observed in the fractionation profile were named P-1 to P-11. Each fraction was concentrated and desalted on an Amberlite IRC-50 (XE-64) column.

Each of P-3 and P-9 dissolved in 10\% acetic acid was chromatographed twice on a Sephadex G-50 column $(2 \times 120 \mathrm{~cm})$. Ten to $20 \mathrm{mg}$ of P-3 or P-9 was dissolved in $3 \mathrm{ml}$ of $10 \%(\mathrm{v} / \mathrm{v})$ acetic acid and applied on a Sephadex G-50 column $(2 \times 120 \mathrm{~cm})$ equilibrated with $10 \%$ acetic acid at $25 \mathrm{C}$. Five-milliliter fractions were collected and the fractions shown by diagonally hatched areas in Figs. 2(a) and 3(a) were each pooled. The pooled fractions were each concentrated to $3 \mathrm{ml}$ and applied to the Sephadex G-50 column again. The fractions shown by diagonally hatched areas in Figs. 2 (b) and $3(\mathrm{~b})$ were lyophilized immediately and named PP-3 (purified P-3) and PP-9 (purified P-9), respectively.

Location of PP-3 and PP-9 in the lysozyme molecule: The amino acid composition of PP-3 and PP-9 were analyzed with an amino acid analyzer (Hitachi KLA-3B). Tryptophan was determined spectrophotometrically by the method of Goodwin and Morton (1946).

Immunization: To estimate the activity of delayed-type hypersensitivity against lysozyme and the digested lysozyme (PP-3 and PP-9), guinea pigs were immunized on the footpads with $200 \mu \mathrm{g}$ of each antigen in complete Freund's adjuvant (Difco Co., Detroit, Mich.).

Skin test: In 9 days after the immunization, intradermal skin tests were performed with $5-40 \mu \mathrm{g}$ of each of P-1 to P-11, PP-3 and PP-9 as antigen. An equal volume of saline was used as control. The injection sites were observed in $24 \mathrm{hr}$; the diameters of induration and erythema were measured. Control animals were immunized with complete Freund's adjuvant alone.

Precipitin test: Antilysozyme serum was obtained from a rabbit by hyperimmunizing with lysozyme purified by Amberlite IRG-50 (XE-64) chromatography as described. Antiserum had a precipitin titer of 512 with $112 \mu \mathrm{g} / \mathrm{ml}$ lysozyme. Precipitin tests were performed by the ring method at concentrations from 8 to $112 \mu \mathrm{g}$ antigen $/ \mathrm{ml}$.

${ }^{3} H$-thymidine incorporation: The procedures described by Dutton and Eady (1964) were employed. The lymph node cells $\left(1 \times 10^{7}\right)$ from the axillary and the inguinal lymph nodes of the guinea pigs taken 13 days after the immunization were cultured with a test sample $(30 \mu \mathrm{g} / \mathrm{ml}$ at a final concentration) in $1.5 \mathrm{ml}$ Eagle's medium (Nissui Seiyaku Co., Tokyo) containing $5 \%$ calf serum (Toshiba Co., Tokyo). In $24 \mathrm{hr}$ of incubation at $37 \mathrm{C}, 0.5 \mathrm{ml}$ of the medium containing $0.2 \mu \mathrm{C}$ of ${ }^{3} \mathrm{H}$-thymidine was added. After further incubation for $24 \mathrm{hr}$, ${ }^{3} \mathrm{H}$-thymidine incorporated into the lymph node cells were counted with a liquid scintilation counter (Packard Co., Downess Grove, Ill.). The ratio of ${ }^{3} \mathrm{H}$ thymidine incorporation in cells added with a test sample to that of control 
was determined.

Migration inhibition test: The test was carried out according to the method of David, A1-Askari, Lawrence and Thomas (1964) with slight modifications. Guinea pigs were immunized with each antigen. In 13 days, $1 \%$ starch-saline solution was injected into the peritoneal cavities of animals, and the peritoneal exudate cells were harvested in 3 days.

The cells were suspended in Eagle's medium containing $5 \%$ calf serum. Capillary tubes were filled with the cell suspension. The tubes were sealed and centrifuged for $5 \mathrm{~min}$ at $900 \mathrm{rpm}$. They were cut at the cell fluid interface and placed in Mackaness-type culture chambers. Chambers were prepared in triplicate. The chambers were filled with Eagle's medium containing $5 \%$ calf serum and the test antigen at various concentrations. The chambers were sealed and incubated for 24-48 hr at $37 \mathrm{C}$. Migration patterns were traced and the areas were measured. The results were expressed as per cent inhibition of migration in chambers containing the antigen in comparison with the migration of cells in chambers containing no antigen.

\section{Results}

\section{Peptic Digestion of Hen Egg-White Lysozyme and Isolation of Peptides}

Hen egg-white lysozyme was digested by pepsin under the condition described in Materials and Methods. The digested lysozyme was fractionated by CMcellulose column chromatography into 11 peaks. The fractionation profile is presented in Fig. 1. Intact lysozyme was eluted in a narrow area showing a peak at the tube No. 300. The ability to elicit delayed-type skin reaction was tested with each fraction in guinea pigs preimmunized with or without lysozyme.

As shown in Table I, P-9 and P-10 were apparently more active than the other fractions; they were as active as intact lysozyme. Though the reaction produced with P-3 was apparently weaker than that with P-9 or P-10, it seemed to be a little stronger than the others. Among the fractions provoking visible skin reaction, P-10 gave positive precipitin reaction with rabbit antilysozyme serum as strongly as did intact lysozyme, though P-9 gave little or no visible precipitation. P-3 showed no precipitation at a concentration from 8 to $112 \mu \mathrm{g} / \mathrm{ml}$. These results may suggest that P-9 was contaminated with intact lysozyme, while P-10 mainly lysozyme itself and P-3 peptic peptide(s) alone.

To clarify whether the delayed-type skin reaction elicited by P-9 was due to the peptic peptide(s) or to the intact lysozyme having contaminated this fraction, further purification of P-9 was carried out by gel filtration on Sephadex G-50 equilibrated $10 \%$ acetic acid (Fig. 2). On this column, intact lysozyme was eluted near tube No. 40. The same procedure was applied also to P-3 (Fig. 3). The final fractions were named PP-9 and PP-3, respectively. No precipitation appeared against the rabbit antilysozyme serum by the ring test with any fraction at a concentration of $112 \mu \mathrm{g} / \mathrm{ml}$, suggesting that PP-9 was not being contaminated with native lysozyme. 


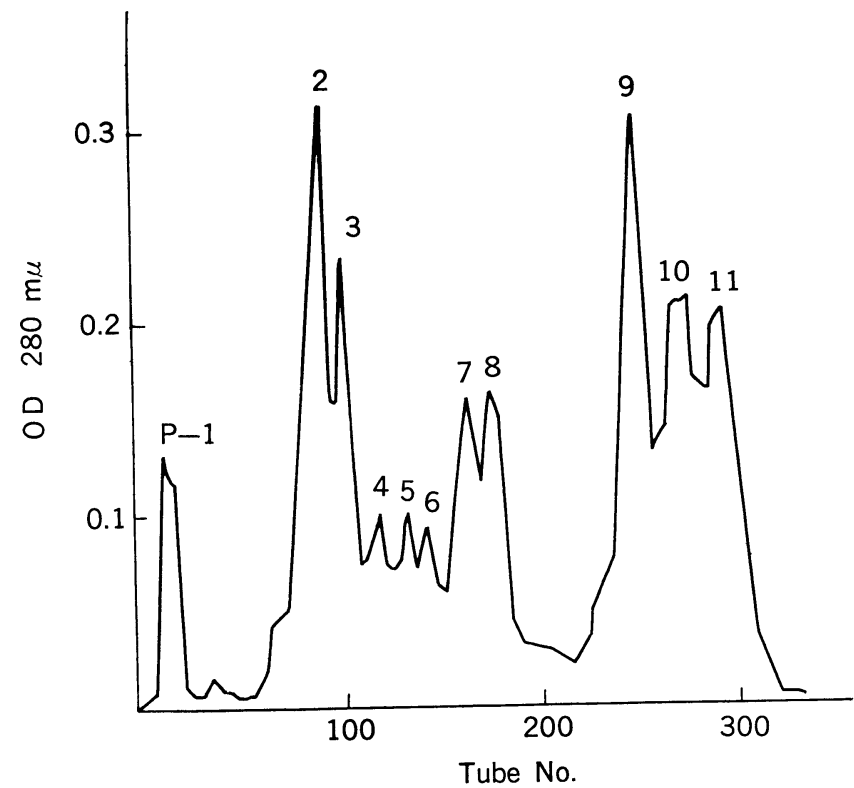

Fig. 1. CM-cellulose column chromatography of peptic digest of hen egg-white lysozyme. Pepsin digest $(300 \mathrm{mg})$ was applied to a CM-cellulose $(0.5 \mathrm{meq} / \mathrm{g}, 200-400 \mathrm{mesh})$, column $(3 \times 40 \mathrm{~cm})$ at $25 \mathrm{C}$. The column was eluted with a linear gradient up to $0.15 \mathrm{M} \mathrm{NaCl}$ in $0.05 \mathrm{M}$ acetate buffer, $\mathrm{pH} 3.85$, followed by a gradient from $0.15 \mathrm{M} \mathrm{NaCl}-0.05 \mathrm{M}$ acetate buffer, $\mathrm{pH} 3.85$, to $0.2 \mathrm{M}$ phosphate buffer, $\mathrm{pH} 8.0$, at a flow rate of $170-180 \mathrm{ml} / \mathrm{hr}$.

TABLE I

Reaction (diameter of erythema in $\mathrm{mm}$ ) in delayed-type skin test with each fraction obtained by CM-cellulose column chromatography

\begin{tabular}{|c|c|c|c|c|c|c|c|c|c|c|c|c|}
\hline \multirow{2}{*}{ Guinea pigs } & \multicolumn{12}{|c|}{ Test Antigen } \\
\hline & Lysozyme & P-1 & $\mathbf{P}-2$ & $P-3$ & $\mathbf{P}-4$ & $P-5$ & $\mathbf{P}-6$ & $\mathrm{P}-7$ & $\mathrm{P}-8$ & P-9 & P-10 & Saline \\
\hline \multicolumn{13}{|l|}{ IMMUNIZED } \\
\hline Mean & 10.1 & 3.5 & 5.0 & 6.4 & 5.6 & 4.7 & 5.5 & 4.0 & 4.7 & 9.9 & 8.0 & 2.2 \\
\hline Range & $7-19$ & $2-5$ & $3-8$ & $3-11$ & $4-9$ & $3-6$ & $3-8$ & $3-5$ & $3-7$ & $5-16$ & $7-9$ & $1-3$ \\
\hline $\begin{array}{l}\text { Number of } \\
\text { animals }\end{array}$ & 17 & 4 & 5 & 7 & 5 & 4 & 2 & 3 & 3 & 12 & 2 & 10 \\
\hline \multicolumn{13}{|c|}{ NON-IMMUNIZED } \\
\hline Mean & 3.2 & 2.8 & 2.2 & 2.6 & & & & & & 2.6 & 3.2 & 2.0 \\
\hline Range & $1-4$ & $2-4$ & $1-3$ & $1-2$ & & & & & & $2-4$ & $1-4$ & $0-3$ \\
\hline $\begin{array}{l}\text { Number of } \\
\text { animals }\end{array}$ & 5 & 5 & 5 & 5 & & & & & & 5 & 5 & 5 \\
\hline
\end{tabular}

Peptic digest $(20 \mu \mathrm{g} / 0.1 \mathrm{ml}$ saline) was injected intradermally into each guinea pig with or without immunization with lysozyme in Freund's complete adjuvant 9 days before. 


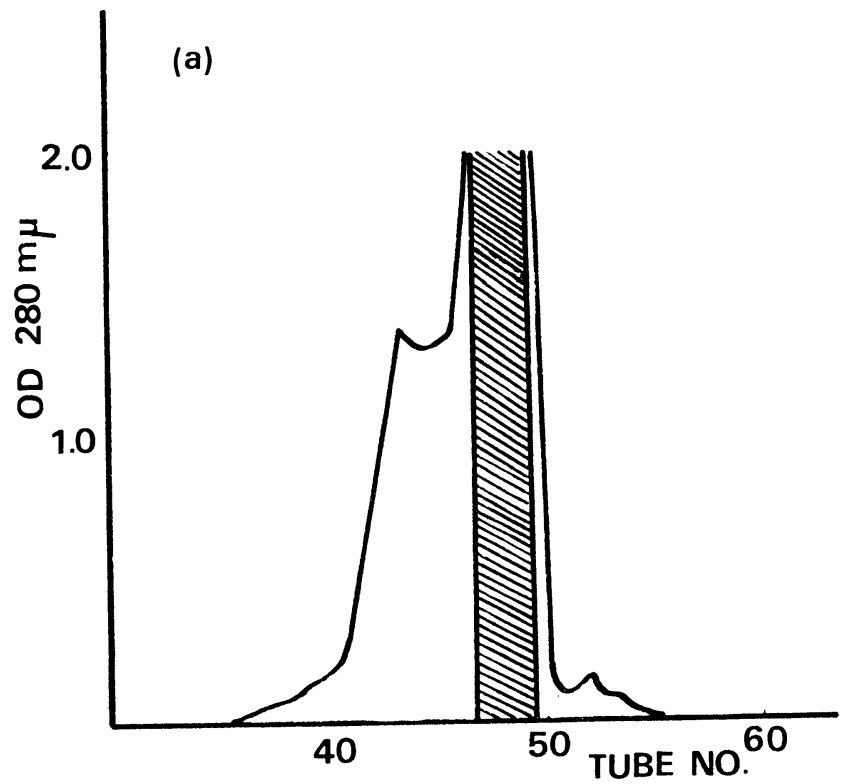

Fig. 2 (a) Gel filtration of crude peptide, P-9, on a Sephadex G-50 column.

Ten to $20 \mathrm{mg}$ of P-9 eluted from a CM-cellulose column was dissolved in $3 \mathrm{ml} \mathrm{of} 10 \%(\mathrm{v} / \mathrm{v})$ acetic acid and applide to a Sephadex G-50 column $(2.0 \times 120 \mathrm{~cm})$. Gel filtration was performed at $25 \mathrm{C}$ and $5 \mathrm{ml}$ fractions were collected. The fractions of a shaded portion (fractions 46 to 49 ) were pooled.

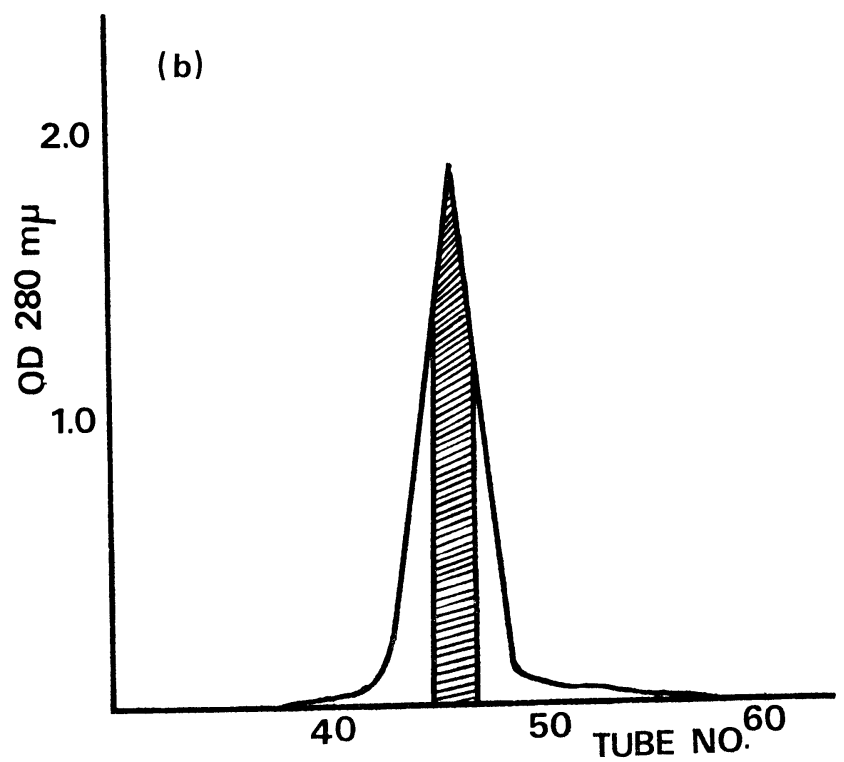

Fig. 2 (b) Refiltration of P-9 on the Sephadex G-50 column.

The shaded portion indicated in (a) was concentrated to $3 \mathrm{ml}$ and applied to the same column as in (a). The shaded portion (fractions 45 to 46 ) indicated in (b) was pooled (PP-9). 


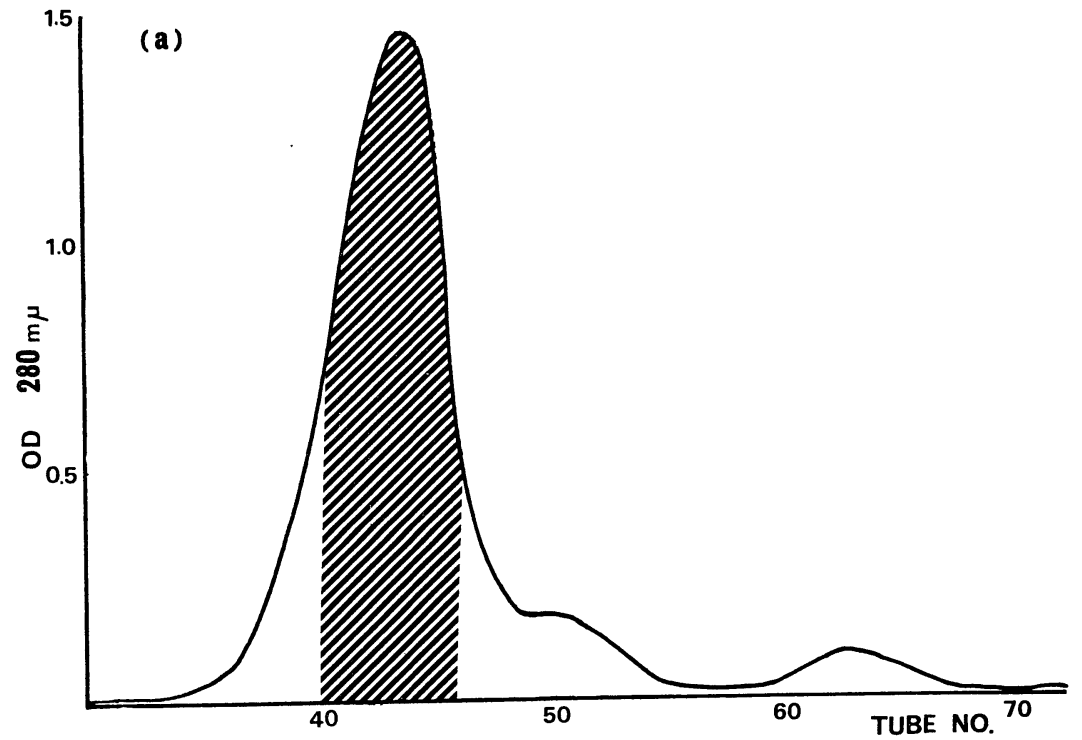

Fig. 3 (a) Gel filtration of crude peptide, P-3, on a Sephadex G-50 column. The shaded portion (fractions 40 to 46 ) was pooled.

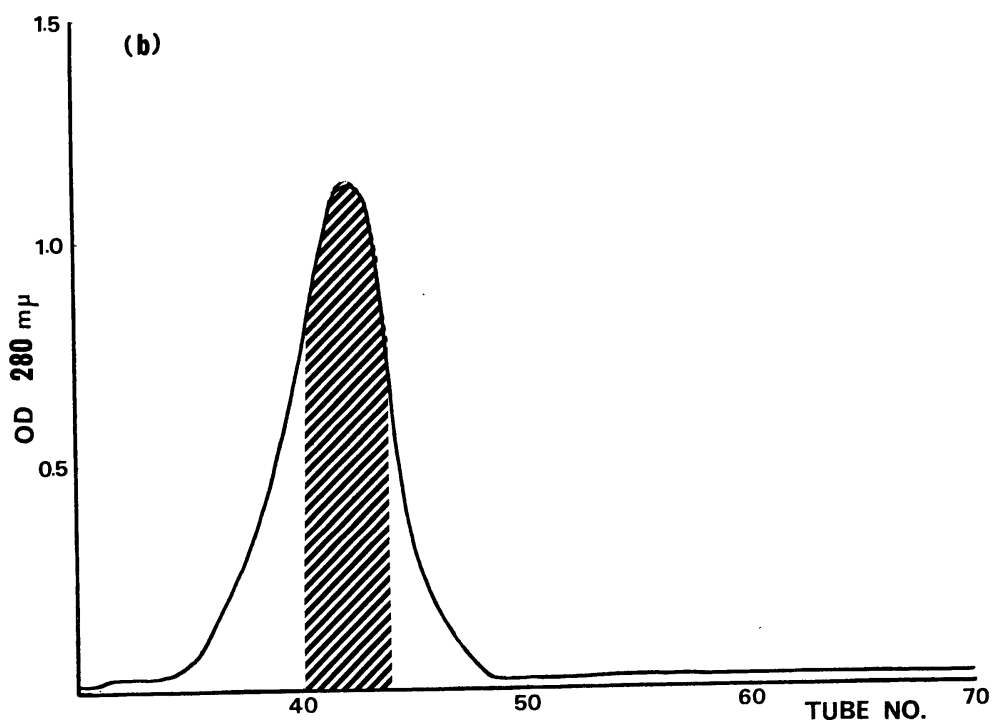

Fig. 3 (b) Refiltration of P-3 on the Sephadex G-50 column.

Experiments were performed similarly as those in Fig. 2. The shaded portion (fractions 40 to 44) was pooled (PP-3). 
TABLE II

Reaction (diameter of erythema in $\mathrm{mm}$ ) of delayed-type skin test, ratio of ${ }^{3} \mathrm{H}$-thymidine incorporation and per cent of migration inhibition, in lysozyme immunized and nonimmunized guinea pigs ${ }^{1)}$

\begin{tabular}{|c|c|c|c|c|c|c|c|c|c|}
\hline \multirow{3}{*}{ Guinea pigs } & \multirow{3}{*}{ Antigen } & & \multicolumn{5}{|c|}{ Delayed-type skin reaction } & $\begin{array}{l}\text { Ratio of }{ }^{3} \mathrm{H} \text {-thymidine } \\
\quad \text { incorporation }{ }^{2)}\end{array}$ & $\begin{array}{c}\text { Migration } \\
\text { inhibition }^{3)}\end{array}$ \\
\hline & & & \multicolumn{5}{|c|}{ Antigen dose $(\mu \mathrm{g})$} & \multicolumn{2}{|c|}{ Antigen dose $(\mu \mathrm{g} / \mathrm{ml})$} \\
\hline & & & 40 & 20 & 10 & 5 & saline & & 60 \\
\hline \multirow{6}{*}{ Immunized } & Lysozyme & Mean & 10.7 & 9.7 & 7.4 & 5.5 & 2.5 & 2.5 & 65.4 \\
\hline & & Range & $9-13$ & $9-11$ & $6-9$ & $5-7$ & $0-3$ & & \\
\hline & PP-9 & Mean & 12.0 & 9.0 & 6.4 & 4.7 & & 3.3 & 59.6 \\
\hline & & Range & 12 & $8-11$ & $6-7$ & $4-6$ & & & \\
\hline & PP-3 & Mean & 3.5 & & & & & 1.1 & 36.2 \\
\hline & & Range & $0-8$ & & & & & & \\
\hline \multirow{6}{*}{$\begin{array}{l}\text { Non- } \\
\text { immunized }\end{array}$} & Lysozyme & Mean & 3.1 & 3.2 & ND & $\left.\mathrm{ND}^{4}\right)$ & 2.0 & 0.8 & 11 \\
\hline & & Range & $2-4$ & $1-4$ & & & $0-3$ & & \\
\hline & PP-9 & Mean & 2.7 & 2.5 & & & & 0.6 & 7 \\
\hline & & Range & $1-3$ & $0-4$ & & & & & \\
\hline & PP-3 & Mean & 2.5 & 2.4 & & & & 0.8 & -3 \\
\hline & & Range & $0-4$ & $0-3$ & & & & & \\
\hline
\end{tabular}

1) All the figures are the means from more than five animals.

2) Each test sample was added at a concentration of $30 \mu \mathrm{g} / \mathrm{ml}$ to a lymph node cell suspension $\left(2 \times 10^{7}\right.$ cells $\left./ \mathrm{ml}\right)$ in Eagle's medium containing $5 \%$ calf serum. After $24 \mathrm{hr}$ of incubation, an additional $0.5 \mathrm{ml}$ of the medium containing $0.2 \mu \mathrm{g}$ of ${ }^{3} \mathrm{H}$-thymidine was added. After additional $24 \mathrm{hr},{ }^{3} \mathrm{H}$-thymidine incorporated into the cells was counted. The ratio was expressed as the amount of incorporation into the cells added with a test sample relative to that without the antigen.

3) The chambers were incubated for $24-48 \mathrm{hr}$ with or without $60 \mu \mathrm{g}$ of each test sample.

4) Not done

\section{Comparison among PP-3, PP-9 and Lysozyme for the Abilities to Elicit Delayed-type Hypersensitivity Reaction}

Five micrograms of PP-9 provoked delayed-type skin reaction in the guinea pig preimmunized with lysozyme as did P-9 and intact lysozyme. In addition, a stronger reaction was observed when a larger dose of PP-9, $40 \mu \mathrm{g}$ per animal, was injected intradermally. PP-3 caused no positive reaction even when $40 \mu \mathrm{g}$ was employed (Table II); $400 \mu \mathrm{g}$ was necessary to produce positive reaction (not presented in the table).

It is well established that both the stimulation of ${ }^{3} \mathrm{H}$-thymidine incorporation into the sensitized lymph node cells and the inhibition of migration of peritoneal cells from the animals sensitized with the antigen are available as the in vitro markers of delayed-type hypersensitivity. Each of PP-9 and intact lysozyme at a concentration of $60 \mu \mathrm{g} / \mathrm{ml}$ inhibited strongly the migration of peritoneal exudate cells from guinea pigs immunized with lysozyme, whereas PP-3 exhibited only a slight inhibitory effect. In the experiment of the ${ }^{3} \mathrm{H}$-thymidine 
TABLE III

Amino acid composition of PP-3 and PP-9

\begin{tabular}{lcccc}
\hline & \multicolumn{2}{c}{ PP-3 } & \multicolumn{2}{c}{ PP-9 } \\
\cline { 2 - 5 } Amino acid residue & $\begin{array}{c}\text { Micro moles/mg } \\
\text { Peptide }\end{array}$ & $\begin{array}{c}\text { Integer } \\
\text { Value }\end{array}$ & $\begin{array}{c}\text { Micro moles/mg } \\
\text { Peptide }\end{array}$ & $\begin{array}{c}\text { Integer } \\
\text { Value }\end{array}$ \\
\hline Lysin & 0.128 & 2 & 0.184 & 2 \\
Histidine & 0 & 0 & 0.084 & $1^{2)}$ \\
Ammonia & 0.333 & 4 & 0.205 & 2 \\
Arginine & 0.121 & 2 & 0.486 & $5-6$ \\
Aspartic acid & 0.773 & 9 & 0.314 & $3-4$ \\
Threonine & 0.166 & 2 & 0.016 & 0 \\
Serine & 0.544 & 6 & 0.073 & 1 \\
Glutamic acid & 0.087 & $12)$ & 0.100 & 1 \\
Proline & 0.170 & 2 & 0.002 & 0 \\
Glycine & 0.352 & 4 & 0.472 & $5-6$ \\
Alanine & 0.333 & 4 & 0.347 & 4 \\
Cystine & 0.217 & 2 & 0.103 & 2 \\
Valine & 0.154 & 2 & 0.160 & 2 \\
Methionine & 0.070 & 1 & 0.074 & 1 \\
Isoleucine & 0.315 & $3-4$ & 0.083 & 1 \\
Leucine & 0.250 & 3 & 0.351 & 4 \\
Tyrosine & 0 & 0 & 0.177 & 2 \\
Phenylalanine & 0 & 0 & 0.103 & 1 \\
Tryptophan & 0 & 0 & 0.092 & 1 \\
\hline
\end{tabular}

1) The values were obtained after hydrolysis of the sample for $24 \mathrm{hr}$ and not corrected for destruction during acid hydrolysis.

2) Glutamic acid and histidine were taken as standards to calculate the amino acid composition for PP-3 and PP-9, respectively.

incorporation, both intact lysozyme and PP-9 were shown to stimulate the uptake of ${ }^{3} \mathrm{H}$-thymidine into the lymph node cells from the immune guinea pigs, while PP-3 did not show any significant increase (Table II).

\section{Location of PP-3 and PP-9 in the Lysozyme Molecule}

The amino acid compositions of PP-3 and PP-9 were analyzed to locate the two fractions within the lysozyme molecule. Table III shows the amino acid compositions expressed as moles of each amino acid residue per mole of each peptide. Glutamic acid and histidine were taken as the standards to calculate the amino acid composition for PP-3 and PP-9, respectively. The minimum molecular weights of peptide PP-3 and PP-9 were calculated to be about 5,400 and 4,800 , respectively, from the results of amino acid analyses.

From these results it is reasonable to conclude that PP-3 corresponds to the region from $\mathrm{Cys}^{64}$ to $\mathrm{Ala}^{107}$ and PP-9 to the region from N-terminal Lys ${ }^{1}$ to $\mathrm{Asn}^{27}$ and from Ala ${ }^{122}$ to C-terminal $\mathrm{Leu}^{129}$ in the amino acid sequence of egg-white lysozyme given by Canfield and Liu (1965). 


\section{Immunogenicity of PP-3 and PP-9}

PP-3 and PP-9 were tested for immunogenicity in guinea pigs. Three guinea pigs each were immunized with $200 \mu \mathrm{g}$ of PP-3 and other three with PP-9 in complete Freund's adjuvant. In 9 days, the delayed-type skin reaction and the ${ }^{3} \mathrm{H}$-thymidine incorporation were examined with PP-3, PP-9 and intact lysozyme as the antigens. Table IV demonstrates an excellent immunogenicity of PP-9; it induced strong delayed-type skin reaction and stimulated ${ }^{3} \mathrm{H}$-thymidine incorporation into the lymph node cells from animals immunized with PP-9 or

\section{TABLE IV}

Delayed-type hypersensitivity in guinea pigs immunized with PP-9

\begin{tabular}{lccc}
\hline \multirow{2}{*}{$\begin{array}{l}\text { Test } \\
\text { antigen }\end{array}$} & \multicolumn{2}{c}{ Delayed skin reaction ${ }^{1)}$} & \multirow{2}{*}{$\begin{array}{c}\text { Ratio of }{ }^{3} \mathrm{H} \text {-thymidine } \\
\text { incorporation }{ }^{2}\end{array}$} \\
\cline { 2 - 3 } & $\begin{array}{c}\text { Antigen dose } \\
(\mu \mathrm{g})\end{array}$ & $\begin{array}{c}\text { Erythema } \\
(\mathrm{mm})\end{array}$ & \\
\hline Lysozyme & 40 & $14.3 \pm 2.85^{3)}$ & 2.3 \\
& 10 & $9.3 \pm 1.25$ & \\
PP-9 & 40 & $13.5 \pm 0.5$ & 3.6 \\
& 10 & $7.3 \pm 1.5$ & \\
PP-3 & 40 & $2.0 \pm 1.0$ & 1.2 \\
\hline
\end{tabular}

1) Three guinea pigs were immunized with $200 \mu \mathrm{g}$ of PP-9 in Freund's complete adjuvant and tested for delayed-type skin reactions 9 days after the immunization.

2) ${ }^{3} \mathrm{H}$-thymidine incorporation into the lymph node cells from guinea pigs immunized with $200 \mu \mathrm{g}$ of PP-9 was tested with $30 \mu \mathrm{g} / \mathrm{ml}$ of each antigen 13 days after the immunization. The values are expressed as the ratio explained in the text.

3) Standard deviation

\section{TABLE V}

Delayed-type hypersensitivity in guinea pigs immunized with $\mathrm{PP}-3$

\begin{tabular}{lcc}
\hline $\begin{array}{l}\text { Test } \\
\text { antigen }\end{array}$ & $\begin{array}{c}\text { Delayed skin reaction } \\
(\mathrm{mm})\end{array}$ & $\begin{array}{c}\text { Ratio of } \\
\text { incorporation }{ }^{2} \text {-thymidine }\end{array}$ \\
\hline Lysozyme & $10.1 \pm 1.2^{3)}$ & 2.1 \\
PP-3 & $10.6 \pm 1.3$ & 2.9 \\
PP-9 & $2.9 \pm 1.2$ & 1.1 \\
\hline
\end{tabular}

1) Three guinea pigs were each immunized with $200 \mu \mathrm{g}$ of PP-3 in Freund's complete adjuvant and tested for delayedtype skin reactions (diameter of erythema) by injection of $40 \mu \mathrm{g}$ antigen 9 days after the immunization.

2) ${ }^{3} \mathrm{H}$-thymidine incorporation into the lymph node cells from guinea pigs immunized with $200 \mu \mathrm{g}$ of PP-3 was tested with $30 \mu \mathrm{g} / \mathrm{ml}$ of each antigen 13 days after the immunization. The values are expressed as the ratio explained in the text.

3) Standard deviation 
intact lysozyme, while PP-3 gave negative results in these examinations.

The animals immunized with PP-3 gave positive reactions of delayed-type hypersensitivity against both PP-3 and lysozyme in a similar degree. However, they did not show any positive reaction against PP-9 as shown in Table V.

All the observations including our demonstration of immunogenicity of PP-9 seem to support our suggestion that the peptide, PP-9, contains the main antigenic determinant for delayed-type hypersensitivity in immunization of the guinea pig with lysozyme.

\section{Discussion}

Shinka et al. (1967) and Fujio et al. (1968) have already demonstrated by equilibrium dialysis that their fraction 7 (the region from $\mathrm{Gln}^{57}$ to $\mathrm{Ala}^{107}$ in the lysozyme molecule) and fraction 17 (the regions from $\mathrm{Lys}^{1}$ to $\mathrm{Asn}^{27}$ and from $\mathrm{Ala}^{122}$ to $\mathrm{Leu}^{129}$ ) isolated from the pepsin digest of hen egg-white lysozyme by CM-cellulose column chromatography had the antigenic activity against rabbit antilysozyme serum. Our analyses of PP-3 and PP-9 for amino acid composition (Table III) revealed that PP-9 coincides well with their fraction 17 and PP-3 with their fraction 7 except for amino acid sequence from $\operatorname{Gln}^{57}$ to $\operatorname{Trp}^{63}$ in the fraction 7 .

PP-9 was almost as active as intact lysozyme in the abilities to elicit delayedtype skin reaction, to inhibit the migration of peritoneal exudate cells and to stimulate lymph node cells obtained from guinea pigs immunized with native lysozyme. Miyagawa et al. (1973) also reported that their fraction 17 (corresponding with our PP-9) inhibited the migration of peritoneal exudate cells of guinea pigs immunized with lysozyme. According to our data (not presented in table) the capacity of PP-3 to elicit delayed-type skin reaction and to inhibit the migration of the peritoneal cells was recognized significantly in guinea pigs immunized with lysozyme when $400 \mu \mathrm{g}$ antigen of PP-3 as provocation was injected intradermally, though the activities were much weaker than those of PP-9. These abilities do not seem to be those of PP-9 or native lysozyme contaminating PP-3. Many fractions were eluted between P-3 and P-9 or lysozyme from CM-cellulose (Fig. 1); P-3 and P-9 were further purified on Amberlite IRC-50 (XE-64) and Sephadex G-50 columns to obtain PP-3 and PP-9, respectively; PP-3 elicited no delayed-type hypersensitivity in guinea pigs immunized with PP-9, nor PP-9 in animals immunized with PP-3 (Tables IV and V). These observations suggest that PP-9 has a major antigenic fragment of lysozyme for inducing delayed-type hypersensitivity and PP-3 also has a slight but significant antigenicity.

In virtually all the guinea pigs, distinct specificities of immunocytes for production of circulating antiglucagon antibody and blast formation suggesting functional dissociation of the bovine glucagon molecule was reported by Senyk et al. (1971). Similar dissociation of the tobacco mosaic virus protein has been reported in the study on antigenic determinant (Spitler et al., 1970). In addition to this type of dissociation, the finding of tuberculin-active carbohydrate induc- 
ing inhibition of macrophage migration but not lymphocyte transformation (Chaparas et al., 1970) suggests another type of dissociation. From these results, Senyk mentioned that glucagon was cleaved by trypsin along functional lines into two parts, one housed the major antigenic determinant ( $\mathrm{N}$-terminal peptide) and the other carried the major immunogenic determinant (C-terminal peptide).

We may not conclude that our results on lysozyme coincide with the findings in glucagon (Senyk et al., 1971). No peptide from tryptic digest of glucagon could function as an immunogen in either antibody formation or delayed-type hypersensitivity, while both peptides, PP-3 and PP-9, from peptic digest of lysozyme were immunogenic. Moreover, it has been found that the main antigenic determinant for producing humoral antibody varied with guinea pig strains used for immunization. In some strains of Hartley, PP-9 gave clear evidence of the major antigenic determinant(s) and in another strain coming from a different colony, so did PP-3. The details will be given in a following report.

Both PP-3 and PP-9 have the immunogenicity for delayed-type hypersensitivity (Tables IV and V), however it is noticeable that the activity of PP-9 in guinea pigs immunized with lysozyme is always stronger than PP-3.

Recent studies on the cellular immune responses to lysozyme and CMlysozyme showed extensive cross reactivity between them in contrast to the lack of humoral cross reactivity (Thompson et al., 1972; Sugimoto et al., 1975). We observed that $\mathrm{N}$-terminal peptide obtained from PP-9 by reduction and S-carboxymethylation was almost as active as PP-9 in eliciting delayed-type hypersensitivity in animals immunized with lysozyme or PP-9 (the data will be given in a following report). These results suggest that the functionally active area may be a part of PP-9 and that it is possible to clarify the definitive determinant for inducing delayed-type hypersensitivity on the lysozyme molecule.

The fact that lysozyme was able to provoke delayed-type skin reaction in guinea pigs immunized with PP-9 suggests that the intact lysozyme molecule is not necessary for inducing the immune response. Perhaps it is required at the level of antigenic determinants on lysozyme that the minimum, essential part is not degraded prior to the induction of the immune response, as mentioned by Schlossman et al. (1969) and Sela et al. (1967).

\section{ACKNowledgement}

We wish to express our sincere gratitude to Prof. Tokukichi Nozima (Institute for Virus Research, Kyoto University) for helpful advice.

\section{REFERENCES}

Canfield, R. E. And LiU, A. K. (1965): The disulfide bonds of egg white lysozyme (muramidase). J. Biol. Chem., 240, 1997-2002.

Chaparas, S. D., Thor, D. E., Godfrey, H. P., Baer, H. and Hedrick, S. R. (1970): Tuberculinactive carbohydrate that induces inhibition of macrophage migration but not lymphocyte 
transformation. Science, 170, 637-639.

David, J. R., Al-Askari, S., Lawrence, H. S. and Thomas, L. (1964): The specificity of inhibition of cell migration by antigens. J. Immunol., 93, 264-273.

Dutton, R. W. And EAdy, J. D. (1964): An in vitro system for study of the mechanism of antigenic stimulation in the secondary response. Immunology, 7, 40-53.

Fujio, H., Imanishi, M., Nishioka, K. and Amano, T. (1968): Antigenic structures of hen egg white lysozyme. II. Significance of the N- and C-terminal region as an antigenic site. Biken J., 11, 207-218.

Goodwin, T. W. ANd Morton, R. A. (1946): Spectrophotometric determination of tyrosine and tryptophan in protein. Biochem. J., 40, 628-632.

Hirs, C. H. W., Moore, S. ANd Stein, W. H. (1953): A chromatographic investigation of pancreatic ribonuclease. J. Biol. Chem., 200, 493-506.

ICHIKI, A. T. AND PARISH, C. R. (1972): Cleavage of bacterial flagellin with proteolytic enzyme. II. Induction of enhanced delayed-type hypersensitivity to flagellin by peptic fragments of the protein. Cell. Immunol., 4, 264-278.

Maron, E., Webb, C., Teitelbaum, D. And Arnon, R. (1972): Cell-mediated vs humoral response in the cross reaction between hen egg-white lysozyme and bovine-lactalbumin. Europ. J. Immunol., 2, 294-297.

Miyagawa, N., Ashizawa, T., Fujio, H. and Amano, T. (1973): The migration inhibitory activity of the peptides of hen egg white lysozyme having antibody binding ability. Abstr. Proc. IIIrd Annu. Meeting Japan. Soc. Immunol.

Schlossman, S. F., Herman, J. ANd Yaron, A. (1969): Antigen recognition: In vitro studies on the specificity of the cellular immune response. J. Exptl. Med., 130, 1031-1045.

Sela, M., Schechter, B., Schechter, I. AND Borek, F. (1967): Antibodies to sequential and conformational determinants. Cold Spring Harbor Symp. Quant. Biol., 32, 537-545.

Senyk, G., Williams, E. B., Niteki, D. E. ANd Goodman, J. W. (1971): The functional dissection of an antigen molecule: Specificity of humoral and cellular immune responses to glucagon. J. Exptl. Med., 133, 1294-1308.

Shinka, S., Imanishi, M., Miyagawa, N., Amano, T., Inoue, M. and Tsugita, A. (1967): Chemical studies on antigenic determinants of hen egg white lysozyme I. Biken J., 10, 89-107.

Spitler, L., Benjamini, E. Young, T. D., Kaplan, H. and Fudenberg, H. H. (1970): Studies on the immune response to a characterized antigenic determinant of the tobacco mosaic virus protein. J. Exptl. Med., 131, 133-148.

Sugrmoto, M., Kojima, A., Yaginuma, K. And Egashira, Y. (1975): Cell mediated and humoral immunity in mice: Cross reaction between lysozyme and S-carboxymethylated lysozyme studied by a modified footpad test. Japan. J. Med. Sci. Biol., 28, 23-35.

Thompson, K., Harris, M. And Benjamani, E. (1972): Cellular and humoral immunity: A distinction in antigenic recognition. Nature New Biol., 238, 20-21. 